\title{
THE POLITICS OF TRANSLATION IN THE CREATION, PRODUCTION, AND CANON FORMATION OF TRANSLATED CEBUANO LITERATURE FROM THE POSTWAR PERIOD TO THE PRESENT
}

\author{
Maria Vanessa Estillore-Gabunada \\ Ateneo de Manila University \\ Visayas State University \\ mvestillore@gmail.com \\ maraivanessa.gabunada@vsu.edu.ph
}

\begin{abstract}
The status of Cebuano literature in the Philippine literary field has been relegated to a marginalized position due to the outbreak of the Second World War and the implementation of English and Filipino as "Mediums of Instruction." As a consequence, the development of Cebuano literature was thwarted. However, prominent Cebuano scholars exerted valuable effort to overcome the marginalized status of Cebuano literature through translation. Through translation, Cebuano literature started to be recognized in the Philippine literary field as translation projects of Cebuano literature were published and canonized. This study looks at the politics of translation and how it influences the production and canon formation of translated Cebuano literature. In doing so, this study traces the historical events from the 1970 s to the 2010 s to situate the narrative of the production process of Cebuano literature translation projects. Using the postcolonial translation theory of Andre Lefevere, this study identifies the constituencies that control the production process and investigates the agenda behind the production of Cebuano literature translation projects. Lastly, this study utilizes John Guillory's theory of the canon, Barbara Herrnstein Smith's contentions of "value/evaluation," and Lawrence Venuti's translation and canonization theory to elaborate how translation has influenced the formation of an alternative canon of Cebuano literature. Finally, this study draws its overall analysis on the material examination of Cebuano literature translation projects and on interviews with the constituencies (translators and publishers) to present the political issues in the production and canon formation of translated Cebuano literature.
\end{abstract}

\section{Keywords}

alternative canon; history; patronages; publication; professionals within the system; selection process; translation projects 


\section{About the Author}

Maria Vanessa Estillore-Gabunada finished her $\mathrm{PhD}$ in English Language and Literature at Ateneo de Manila University. She is teaching translation and research planning at Visayas State University. Her research interests include regional literature, translation, language policy issues, and language studies. She is currently working on collecting Baybayanon literature.

Kritika Kultura 33/34 (2019/2020): 248-274

(c) Ateneo de Manila University

<http://journals.ateneo.edu/ojs/kk/> 
Cebuano literature is an expression of the character and culture of the largest linguistic sector in the Filipino nation inhabiting central Visayas, most of eastern Visayas, eastern Mindanao, and the greater part of northern and central Mindanao (Maceda 381). It is an abundant literature in its oral form, which includes folktales, sayings, songs, riddles, and speeches. Its written form comprises works written specifically for publication, such as poems, short stories, novels, and plays (Ramas 212). Although scarred by Spanish colonialism and marginalized by the American educational system, Cebuano literature flourished through difficult periods in Philippine history and today has managed to survive despite the paucity of outlets (Maceda 381).

After World War II, Cebuano writers were confronted by a dearth of periodicals and, more seriously, by the increasing marginalization of their works in Cebuano society. According to Cebuano scholar Teresita Maceda, Cebuano writers addressed the deteriorating situation by forming organizations like Cebu Writers Organization (CWO) in 1953 and the Lubas sa Dagang Bisaya (Core of Visayan Writing) or LUDABI in 1956 (385). CWO helped revitalize Cebuano writing by circulating Bisaya, a yearly selection and critical review of the best poems, short stories, and serialized novels from 1954 to 1956. LUDABI, on the other hand, became the refuge of serious writers when it became increasingly difficult to find outlets for their creative works. It actively promoted Cebuano writing by sponsoring annual literary contests and publishing a quarterly literary magazine (though short-lived) and anthologies of winning short stories and poems. Moreover, Cebuano literature experienced a surge in literary production as university-schooled young writers like Godofredo Roperos and Tiburcio Baguio actively involved themselves in the editorial staff of Bisaya magazine. Working with Editor-in-chief Francisco Candia, they initiated steps to raise the literary standard and to "improve" the literary taste of readers (Maceda 385). To encourage more serious writing, they increased the number of short stories published weekly from three to nine, even as they applied stricter norms in selecting stories to be published. However, the experiment of turning an essentially commercial magazine into a literary one was halted in 1957 because of financial losses resulting from a drop in circulation. Serious writers suddenly found themselves with no outlet though editors occasionally managed to squeeze in a few literary works when they felt secure that these would not affect the sales of the magazine.

In the 1960 s, the situation was further aggravated by the demand for sex-oriented stories, a direct result of the popularity of the "bomba" films. Commercialism has thus limited and hampered the growth of Cebuano literature. The ephemeral nature of commercial magazines has also been the reason why many literary works in Cebuano have never been recognized as part of the rich cultural heritage of the Cebuano-speaking world (386). Moreover, many young Cebuano writers in 
Cebuano do not really have a sense of the tradition of Cebuano literature because more students prefer to write in English than in Cebuano. It was also frustratingly difficult to get students to write in Cebuano (Bresnahan, 140).

In the 1970s, criticism on the condition of Cebuano literature started to come out as preliminary studies showed the scarcity of research and scholarly studies on Cebuano literature and its tradition. These preliminary studies focused on surveying sources of Cebuano literary studies, research projects, and symposia on the condition and significance of Cebuano literature. The common goal of these preliminary studies was to call for more scholarly attention to Cebuano literature. However, conditions have changed in the late 1970 s to 1980 os as studies on vernacular literature gradually increased. This period was considered as the rise of regional literature as more and more attention was given to studying the literary history of vernacular literature through research projects, collaborations, and publications. This movement of studying vernacular literature was in line with the campaign for the formation of a national literature that should represent the literary traditions of the different Philippine regions. This campaign was supported by different unions and Philippine scholars. One of these is the SALAPI (Samahan para sa mga Literatura ng Pilipinas) which stated that "Philippine literature, to be a genuine national literature, should not be composed only of literature in only one language of one ethnic group" (Puente 29). Moreover, Elmer Ordoñez argued that what is needed is the creation of a Philippine literary history using all the regional literatures as component parts for the future of writing in the country, and this lies in the emergent literature as written by the marginalized and dispossessed (Bresnahan 133). Agreeing with this notion, Rolando Tinio remarked, "at the moment, it is difficult to characterize the national literary sensibility because great bulk of vernacular literature has remained uncollected" (cited in Mojares, "Do Regional Literatures Exist Today" 128). Bienvenido Lumbera also emphasized that "there was a need for the revision of the literary history of the Philippines and that, in this revision, we needed to have a clearer appreciation of the mainstream of this history, which is constituted by the literature in the various Philippine languages" (Mojares, 128).

Due to these historical developments, the emergent interest in forming a national literature brought much-needed attention to regional literature, particularly to the vernacular. This literary and cultural development that started in the 1970s up to 198 os was called the "rise of regional literature," while the "national literature" would be the term reserved for all the vernacular literature in the Philippines. In response to this, there was a developing thrust toward the retrieval and the recuperation of writings in Philippine languages other than Tagalog and English. With the rise of regional literature, much progress has been achieved in integrating writing from the regions into the national literature of the Philippines as national agencies as 
such the Cultural Center of the Philippines (CCP), Komisyon sa Wikang Filipino (KWF), and National Commission for the Culture and the Arts (NCCA) supported the initiatives for the formation of a national literature that includes the regional literature in the Philippines.

Indeed, a great deal of progress has been made in the recovery of regional literary traditions as bibliographies, historical surveys, anthologies, and studies of individual writers have been produced. With more research outputs on various vernacular literature, the growth of Philippine "national literature" has thus expanded, and the national audience is now ready to read literary works originating from the regions for whatever fresh subject matter and insights these might offer (Lumbera, Filipinos Writing 381).

However, it is important to emphasize that the process of forming a national literature that integrates all the regional literature is a difficult task that needs the aid of translation. This means that the literature from the regions which appears in national literary magazines and anthologies presents a translation of the original literary works into English and Filipino. This is because not all Filipino readers can understand the regional languages in which these works are originally written. As a solution to the possible problem of unintelligibility and unreadability, translation of regional literature into English and Filipino has to be done so that the Filipino readers can comprehend the works. Undeniably, translation is a part of the formation of a national literature. With this, Cebuano scholar Erlinda Alburo emphasizes that translation would be a great help in the building of national literature ("Notes on the Language Issue" 315). This is further supported by Hiligaynon scholar Corazon Villareal as she notes that translation between and among regional languages is needed in order to develop a literature based on all regional languages (Puente 41). Even Lumbera approves of the same argument as he further explains that the growth of any national literature is always abetted by its contacts with regional literatures, and translations are the records of these contacts. The literary merits of translations are not half as important as the information they provide in the entry of certain literary types and themes into national literature (Lumbera, "The Literary Relations of Tagalog Literature" 40). This suggests that the translation of regional literature should be considered to contain the same literary merits with the original as the translation makes possible the comprehension of regional literature to a wider Filipino readership. Through this, the politics of building a national literature elevates the craft of translation from a purely functional role as a teaching aid to a vital link in the politicization process of a community as it becomes a necessary tool in the understanding of regional literature. Indeed, the 
importance of translation in building the national literature underscores the need to continue translating works from the different Philippine languages (Puente 46).

Consequently, the translation of regional literary works requires the attention of Filipino translators. But in this process, translators are caught in the middle of language issues. They are confused as to what target language (English or Filipino) the translation should be done. This is because there are separate directions in translating regional literature. On the one hand, there is an effort to translate regional literature into Filipino as it is the national language of the Philippines. On the other hand, there is also a separate effort to translate regional literature into English as it is one of the official languages of the Philippines. Thus, a division in terms of language choice in translation is created, even among Filipino scholars. For instance, Isagani Cruz encourages writers in English, who also want to write in Filipino, not to bother writing in Filipino. Instead, they should translate Philippine works into English for, in this way, the writers in the Philippine languages will be read abroad and also by Filipinos caught in an English-language cocoon (Ordoñez 74). On the other hand, Rolando S. Tinio, who stopped writing English poems i response to "the language problem," launches a grand project of translating modern Western drama into Filipino for his theater company, introducing various American and European playwrights to Filipino audiences (Lumbera, "Versus Exclusion" 186).

The unresolved language choice issue in translation also affects the production of Cebuano literature translation projects as Cebuano literary works were translated into Filipino and English. Other than the language choice that causes a separation in the translation of Cebuano literature, the gathered data also shows that there are international, national, and regional agencies that have controlled the publication of Cebuano literature translation projects. Apparently, these agencies have opposing agendas that greatly influence the flow of Cebuano literature translation projects.

\section{THE PRODUCTION OF CEBUANO LITERATURE TRANSLATION PROJECTS}

As emphasized above, the inclusion of Cebuano literature in the formation of the national literature requires the use of translation. Thus, Cebuano literature has been translated into English and Filipino. Based on the data, the publication of Cebuano literature translation projects into Filipino and English started from 1970s up to the 21st century. In the inclusive decades, translation of Cebuano literature had been published by regional, national, and international translation programs. From this, it can be inferred that there are indeed factors that control the publication of Cebuano translation projects. Lefevere's theory of translation as rewriting explains these factors. Lefevere contends that "translation is the most obviously recognizable 
type of rewriting, and ... it is potentially the most influential because it is able to project the image of an author and/or those works beyond the boundaries of their culture of origin" (9). Lefevere's theory focuses on the examination of the "very concrete factors that systemically govern the reception, acceptance or rejection of literary texts; that is, issues such as power, ideology, institution and manipulation" (9). This means that the institutions (agencies) have the power to manipulate the ideology that governs the literary texts for its reception or rejection. Thus, Lefevere describes the literary system in which translation functions as being controlled by three main factors: professionals within the literary system, patronages, and the dominant poetics (9). Given the periodization of the published Cebuano literature translation projects and Lefevere's main factors that control translation, the discussion of each translation project is elaborated by the four categorizations or defining tendencies to which Cebuano literature translations belong. These four categories are the following: (1) patronages, (2) the scope and focus of the translation programs, (3) the dominant poetics, and (4) the professionals within the system. Patronages refer to regional, national, and international programs that fund and control the publication of Cebuano literature translation projects. The scope and focus explain the specific purpose, focus, and conditions of the different translation programs. The dominant poetics refers to the target language preferences, which are Filipino and English. Finally, the professionals within the system refer to the Cebuano scholars and translators responsible for the selection and translation of Cebuano literary works included in the projects.

These defining tendencies or categorizations of translation projects of Cebuano literature in each period are only representative (not exhaustive) in nature, given the limited research done on this topic. The periodization and categorization of Cebuano literature translations are shown in the following table. 
Table 1. Periodization and Categorization of Cebuano Literature Translations from the 1970 s to the 2010s.

\begin{tabular}{|c|c|c|c|}
\hline \multicolumn{4}{|c|}{ Cebuano Literature Translation Projects in the 1970s } \\
\hline $\begin{array}{l}\text { Translation } \\
\text { Programs and } \\
\text { Projects } \\
\text { (Patronages) }\end{array}$ & Scope and Focus & $\begin{array}{l}\text { Dominant } \\
\text { Poetics }\end{array}$ & $\begin{array}{l}\text { Professionals } \\
\text { within the } \\
\text { System }\end{array}$ \\
\hline $\begin{array}{l}\text { Manunulat: } \\
\text { Mga Piling } \\
\text { Akdang } \\
\text { Pilipino }\end{array}$ & $\begin{array}{l}\text { - Pagtitipon ng mga literatura } \\
\text { upang mahubog ang kaisipan } \\
\text { ng kabataan sa pagmamahal ng } \\
\text { sariling wika (Filipino) } \\
\text { - Pagkakaisa sa Pakikibakang } \\
\text { Panliteratura } \\
\end{array}$ & - Filipino & $\begin{array}{l}\text { - } \begin{array}{l}\text { Nazarion } \\
\text { Bas }\end{array} \\
\end{array}$ \\
\hline $\begin{array}{l}\text { Cebuano } \\
\text { Studies } \\
\text { Center (CSC) } \\
\text { Translation } \\
\text { Projects }\end{array}$ & $\begin{array}{l}\text { - To collect and translate of pre- } \\
\text { colonial Cebuano literature } \\
\text { - To respond to the rise of } \\
\text { vernacular literature and the } \\
\text { formation of national literature } \\
\text { through translation. }\end{array}$ & - English & $\begin{array}{ll}\text { - } & \text { Erlinda } \\
& \text { Alburo }\end{array}$ \\
\hline \multicolumn{4}{|c|}{ Cebuano Literature Translation Projects in the $1980 \mathrm{~s}$} \\
\hline $\begin{array}{l}\text { Solidarity } \\
\text { Translation } \\
\text { Series }\end{array}$ & $\begin{array}{l}\text { - A full-scale project of translation } \\
\text { into English and Filipino of books } \\
\text { in literature, humanities, and } \\
\text { social sciences authored by } \\
\text { writers and intellectuals from } \\
\text { Southeast Asia. } \\
\text { - A partnership with Solidarity } \\
\text { journal in pioneering translation } \\
\text { projects to help shape the } \\
\text { academic and scientific } \\
\text { vocabulary of Filipino. }\end{array}$ & - English & $\begin{array}{ll}\text { - Erlinda } \\
\text { Alburo } \\
\text { - Vicente } \\
\text { Bandillo } \\
\text { - Simeon } \\
\text { Dumdum } \\
\text { - Resil } \\
\text { Mojares }\end{array}$ \\
\hline \multicolumn{4}{|c|}{ Cebuano Literature Translation Projects in the 1990s } \\
\hline $\begin{array}{l}\text { Panitikan } \\
\text { Series }\end{array}$ & $\begin{array}{l}\text { - To publish or reprint important } \\
\text { literary works that must be read } \\
\text { by students of literature and } \\
\text { Philippine Culture } \\
\text { - To translate into Filipino the } \\
\text { literature of the major languages } \\
\text { of the Philippines } \\
\text { - To help the national language be } \\
\text { used as the standard language of } \\
\text { literary research in the Philippines } \\
\text { - To translate various Cebuano } \\
\text { literature }\end{array}$ & - Filipino & $\begin{array}{ll}\text { - } & \text { Erlinda } \\
& \text { Alburo } \\
\text { - } & \text { Resil } \\
\text { Mojares } \\
\text { - Don } \\
\text { Pagusara }\end{array}$ \\
\hline
\end{tabular}




\begin{tabular}{|c|c|c|c|}
\hline $\begin{array}{ll}\text { - } & \text { Aklat } \\
\text { Bahandi } \\
\text { Series }\end{array}$ & $\begin{array}{l}\text { - Pagsasalin sa Filipino ng mga } \\
\text { klasikong akda sa dayuhang wika } \\
\text { at mga wika sa rehiyon } \\
\text { - Pagsisikap na lumikha ng } \\
\text { tekstong nagtataguyod sa pag- } \\
\text { unlad ng pambansang panitikan } \\
\text { sa tulong ng ambag mula sa mga } \\
\text { rehiyon sa Filipinas at panitikan } \\
\text { ng daigdig. } \\
\text { - Layunin ng koleskyong ito na } \\
\text { maipabasa sa mga Filipino ang } \\
\text { mga orihinal na tekstong Sebuano } \\
\text { at ang salin sa Filipino ng } \\
\text { labindalawang kwento ni Vicente } \\
\text { Sotto. }\end{array}$ & - Filipino & $\begin{array}{ll}\text { - } & \text { Erlinda } \\
& \text { Alburo } \\
\text { - } & \text { Remedios } \\
\text { Ramos }\end{array}$ \\
\hline \multicolumn{4}{|c|}{ Cebuano Literature Translation Projects in the 2010s } \\
\hline $\begin{array}{l}\text { Sentro } \\
\text { ng Wika } \\
\text { Translation } \\
\text { Project }\end{array}$ & $\begin{array}{l}\text { - Makagawa ng direktang } \\
\text { koneksyon sa pagbuo ng } \\
\text { pambansang literatura at } \\
\text { ang patuloy na pagbuo, } \\
\text { pagpapalawak at pagpapayaman } \\
\text { ng Wikang Filipino. } \\
\text { - Makikilala ang mga literaturang } \\
\text { rehiyunal sa pamamagitan ng } \\
\text { pagsasalin nito sa Wikang Filipino. } \\
\text { - Pangingibabaw ng damdaming } \\
\text { rehiyunalismo }\end{array}$ & - Filipino & $\begin{array}{l}\text { - Lededica } \\
\text { Leyson, } \\
\text { - Flora } \\
\text { Empuerto, } \\
\text { Romeo } \\
\text { Macan, } \\
\text { - Avita A. } \\
\text { Perez, } \\
\text { - Godfrey } \\
\text { Montera, } \\
\text { - Geraldine } \\
\text { Rebamonte, } \\
\text { - Rowena C. } \\
\text { Largo. }\end{array}$ \\
\hline $\begin{array}{ll}\text { - } & \text { CSC } \\
\text { Translation } \\
\text { Project }\end{array}$ & $\begin{array}{l}\text { - To devote to studies pertaining to } \\
\text { Cebu in the area of the humanities } \\
\text { and social sciences } \\
\text { - To answer to the growing demand } \\
\text { for research services in local } \\
\text { history and vernacular literature } \\
\text { - A local/regional research center } \\
\text { in the country, through its varied } \\
\text { activities in the conduct and } \\
\text { promotion of local/ regional } \\
\text { studies. }\end{array}$ & - English & $\begin{array}{l}\text { Erlinda } \\
\text { Alburo }\end{array}$ \\
\hline $\begin{array}{l}\text { Solidarity } \\
\text { Translation } \\
\text { Series }\end{array}$ & $\begin{array}{l}\text { - A full-scale project of translation } \\
\text { into English and Filipino of books } \\
\text { in literature, humanities, and } \\
\text { social sciences authored by } \\
\text { writers and intellectuals from } \\
\text { Southeast Asia. } \\
\text { - A partnership with Solidarity } \\
\text { journal in pioneering translation } \\
\text { projects with the aim of helping } \\
\text { shape the academic and scientific } \\
\text { vocabulary of Filipino. } \\
\text { - Translations of various Cebuano } \\
\text { literature }\end{array}$ & - English & $\begin{array}{ll}\text { - Erlinda } \\
\text { Alburo } \\
\text { - Vicente } \\
\text { Bandillo } \\
\text { - Simeon } \\
\text { Dumdum } \\
\text { - Resil } \\
\text { Mojares }\end{array}$ \\
\hline
\end{tabular}




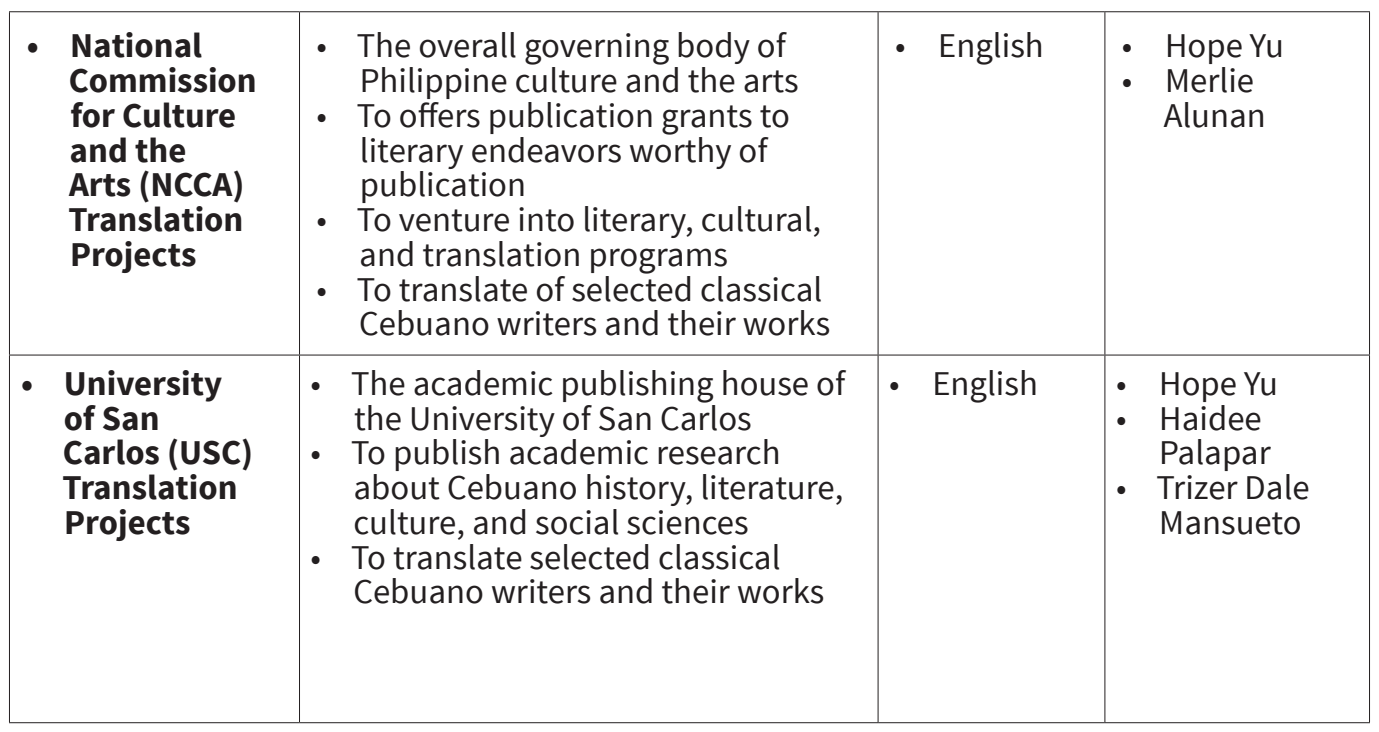

\section{Translation Programs/Projects: Patronages and their Scope and Focus}

As an initial response to the campaign toward the formation of a national literature in the 1970s, three Cebuano literature translation projects were created. One of them was translated into Filipino, and the other two were translated into English. Aside from the different target language choice, these are different translation projects. The translation of Cebuano literature into Filipino belongs to the anthology Manunulat: Mga Piling Akdang Pilipino. The scope of this translation project does not only include Cebuano literature but also other vernacular literatures, such as Hiligaynon, Ilokano, and Kapampangan, to mention a few. The different vernacular literatures included in this anthology are written and/or translated by regional writers. Particularly, the Cebuano short stories included in this anthology are translated by Nazarion Bas. The goal of this translation project is to form a national literature using the Filipino language. On the other hand, Cebuano literature translation projects into English were carried out by the Cebuano Studies Center of the University of San Carlos. The Cebuano Studies Center was first conceived in 1972 and was established in 1975 as an answer to the growing demand for research services in Cebuano local history and literature. From then on, the center has become an active instrument in encouraging and supporting research activities within the university in the areas of the social sciences and the humanities. Most importantly, it has become a model of its kind as a local/regional research center in the country through its conduct and promotion of local/regional studies (Cebuano Studies Center). From the description of the center, it is clear that it was founded as an institution to establish Cebuano literature in particular and a sense of region in general by encouraging scholars to conduct studies that would 
unite the strewn and isolated Cebuano literary works after the Second World War. The Cebuano Studies Center translates Cebuano literature to English as it offers a wider readership.

Moreover, in the 1980 os to 1990 , the Toyota Foundation actively provided assistance for research on the regional culture, literature, and history of Southeast Asia based on the theme of preserving and revitalizing indigenous cultures. The Toyota Foundation provided financial grants to research projects that addressed regional themes spanning national borders and to projects designed to build networks among the researchers and scholars of Southeast Asian countries. Due to this, Toyota Foundation launched the "Know Our Neighbours' TranslationPublication Programme in Other Asian Countries" which covered translation and publication related expenses in order to encourage the translation and publication in Southeast and South Asian countries of literary works on the culture, society, and history of these countries as well as Japan (Toyota Foundation). Under this translation program from Toyota Foundation, the Solidarity Translation Series was created in the 1980 s, in collaboration with Solidarity journal founded by F. Sionil Jose. The Solidarity journal was established in 1965 with funding from the Congress for Cultural Freedom (Sionil 9). Solidarity addressed broader issues such as politics, economy, colonialism, and regionalism as it welcomed different contributors from Europe and the Southeast Asian region (9). With a wide list of contributors coming from Southeast Asia, Solidarity established collaborations with different foundations such as the Ford Foundation, the Rockefeller Brothers Fund, OBOR, NOVIB in Holland, and of course the Toyota Foundation of Japan (14). Thus, since 1985, Solidarity has received a generous grant from the Toyota Foundation to publish Southeast Asian books translated into Filipino, English, Cebuano, and Ilokano. With this program, Solidarity also pioneered a translation series of regional literatures into English to help shape the academic and scientific vocabulary of Filipino, a project that contributed to the development of a national literature. Thus the Solidarity Translation Series was created.

The Solidarity Translation Series is a full-scale project of translation into English of books in literature, humanities, and social sciences authored by writers and intellectuals from Southeast Asia (Zafra 6). The Solidarity Translation Series positions itself against the grain of the history of translation in the Philippines. For a long time, the direction of translation has been focused on the West, thus within the Southeast Asian context, Solidarity Translation Series wants, through translation, to establish the literatures of the Southeast Asian region, including the Philippines, to show the West that the countries in the region have their own literature that is worthy of international readership. Moreover, within the Philippine context, Solidarity Translation Series wants to establish the literature from the regions for the development of a national literature using English language. 
It must be emphasized that the Solidarity Translation Series translates regional literature into English as it aims for wider readership within the Philippines, Southeast Asia, and beyond.

Meanwhile, in the 1990s, Nicanor G. Tiongson initially proposed to establish a consortium of the presses of three major universities in the country-the University of the Philippines, Ateneo de Manila University and De La Salle University (Alburo, et.al., Panulaang Cebuano ix). The goal of the Panitikan Series is to publish or reprint important literary works that must be read by students of literature and Philippine culture. The translation of Cebuano literature (and other vernacular literature) into Filipino is expected to give a wide coverage for the term "Panitikan ng Pilipinas" or Philippine literature (ix). The choice of Filipino language in translation is supported by the rationale that Filipino is the "sister language of the native languages, and will most effectively communicate the feel, color, and rhythm of the original language" (xi). Furthermore, the Panitikan Series hopes that, through the practice of translation, the national language (Filipino) will finally be used as the standard language of literary research in the country. Aside from the Panitikan Series, the Komisyon sa Wikang Filipino (KWF) also produces translation projects of Cebuano literature into Filipino. The first translation project that the KWF published is under the Aklat Bahandi Series of the University of the Philippines Sentro ng Wikang Filipino (UP-SWF). The Aklat Bahandi Series aims to translate international, national, and regional literary works to the Filipino language.

Furthermore, the campaign for the formation of national literature through translating regional literature continues until the 21st century as more Cebuano literature translation projects are produced by KWF Sentro ng Wikang Filipino, NCCA, and University of San Carlos Press. The last translation project of Cebuano literature into Filipino is produced under the Panrehiyong Sentro ng Wikang Filipino Region VII located at Cebu Normal University in Cebu City with a funding coming from KWF. This particular project also translates Cebuano literature to the Filipino language.

Meanwhile, the NCCA, as an overall governing body of Philippine culture and the arts, offers publication grants to literary endeavors from the regions provided that they will be written/translated into English. With this publication grant, more translation projects of Cebuano literature into English are produced through the efforts of Hope S. Yu (the current director of CSC). Moreover, the University of San Carlos Press also ventures into publication of Cebuano literature translated into English with the aim of establishing regional translation projects that are independent from national influences. Again, these translation projects are initiated by $\mathrm{Yu}$ together with other USC faculty translators. In an interview, Yu says that she is positive that more translation projects of Cebuano literature are 
in the pipeline, waiting to be published in the years to come especially since the Cebuano Studies Center is now planning to venture into Filipino translation of more Cebuano literature through KWF grants (Yu, interview, March 2017).

In the discussion of different translation programs/projects published by different patronages from 1970 s to the 21st century, it is evident that the different patronages imposed on using different target languages in translating Cebuano literature. For instance, the Manunulat anthology, Aklat Bahandi Series, Panitikan Series, and KWF imposed on translating to the Filipino language, while the CSC, Solidarity Translation Series, NCCA, and USC imposed on translating to the English language. Due to this imposition, Cebuano literature translation projects into Filipino and English were produced. Most importantly, these patronages have unintentionally formed a national literature in Filipino and in English. Thus, instead of forming a national literature that unites the different regional literatures using one language, the translation projects of Cebuano literature into Filipino and English have intensified the separation and competition of these two languages. This competition in terms of the language choice of translation is elaborated below.

\section{Dominant Poetics: Target Languages of Translation}

Dominant poetics is one of the factors that controls the translation projects of Cebuano literature. In describing dominant poetics, Lefevere focuses on the role of institutions in determining and enforcing the eminent standard of a particular period by using it as the yardstick against which current production is measured. In the case of Cebuano literature, the eminent standard enforced in its publication (since the 1970s) is the use of translation. Thus the patronages mentioned above imposed that the production of Cebuano literature must have Filipino or English translation. Given that there is an imposed target language, I take the idea of dominant poetics to refer to the language preference issues in the translation of Cebuano literature. Therefore, in this context, the conventional definition of poetics which refers to the theory that determines the creative practice of translation, that is, the philosophy of the translator in translating the materials, does not apply. The re-definition of poetics in this context refers to the ideology that there is a greater dominant poetics (preferred target language in translation) than the one institutionally imposed (translation as standard of publication) in the production

of Cebuano literature translation projects. Thus, the examination of language preference issues in translation would show the dominant target language (poetics) used in the translation projects of Cebuano literature. 
As evident in the gathered data, there are Cebuano literature translation projects into Filipino and English. The tables below show the list of Cebuano literature translation projects into Filipino and English as well as which target language dominates in the publication of Cebuano literature translation projects.

Table 2. List of Cebuano Literature Translation Projects into Filipino

\section{List of Cebuano Literature Translation Projects into Filipino}

1. Alburo, Erlinda, Resil Mojares, and Don Pagusara, editors. Panulaang Cebuano. Ateneo de Manila UP, 1993. (Panitikan Series)

2. Alburo, Erlinda, Resil Mojares, and Don Pagusara, editors. Dulaang Cebuano. Ateneo de Manila UP, 1997. (Panitikan Series)

3. Ramos, Remedios B. Labindalawang Kuwento ni Vicente Sotto. UP Sentro ng Wikang Filipino, 1998. (Aklat Bahandi Series)

4. Leyson, Lededica, Flora Empuerto, Romeo Macan, Avita A. Perez, Godfrey Montera, Geraldine Rebamonte, Rowena C. Largo, editors. Mga Piling Literaturang Sugbuanon. PSWF R-VII, 2008. (Sentro ng Wika Translation Series)

Table 3. List of Cebuano Literature Translation Projects into English List of Cebuano Literature Translation Projects into English

- 1. Alburo, Erlinda K. Cebuano Folktales 1 and 2. University of San Carlos Publications, 1977. (CSC Translation Project)

- 2. Alburo, Erlinda K. Cebuano Folksongs 1. University of San Carlos Publications, 1978. (CSC Translation Project)

- 3. Alburo, Erlinda et. al., editors. Cebuano Poetry: Sugbuanong Balak, Until 1940. Cebuano Studies Center, 1988. (Solidarity Translation Series)

- 4. Alburo, Erlinda et. al., editors. Cebuano Poetry: Sugbuanong Balak, 1940-1988. Cebuano Studies Center, 1988. (Solidarity Translation Series)

- 5. Alburo, Erlinda et. al., editors. Sugilanong Sugbuanon: Cebuano Fiction, Until 1940. Ateneo de Manila UP, 2009. (Solidarity Translation Series)

- 6. Alburo, Erlinda et. al., editors. Sugilanong Sugbuanon: Cebuano Fiction, 1940-2005. Ateneo de Manila UP, 2009. (Solidarity Translation Series)

- 7. Alburo, Erlinda K. Tigmo ug Sanglitanan: Cebuano Riddles and Proverbs. Cebuano Studies Center, 2002. (CSC Translation Series)

- 8. Yu, Hope S, translator. Ang Inahan Ni Mila/Mila's Mother: A Novel by Austregelina Espina-Moore. National Commission for Culture and the Arts, 2008. (NCCA Translation Projects) 
- 9. Yu, Hope S., translator. Men at Sea and Other Stories. NCCA, 2009. (NCCA Translation Projects)

- 10. Yu, Hope S., translator. Diin May Punoan sa Arbol/ Where a Fire Tree Grows. University of San Carlos Publication, 2010. (USC Translation Projects)

- 11. Yu, Hope S., translator. Crack Shot and Other Short Stories. U of San Carlos P, 2010. (USC Translation Projects)

- 12. Yu, Hope S., and Haidee Emmie K. Palapar, translators. Himaya nga Nabanhaw ug Uban pang mga Sugilanon/ Reawakened Bliss. U of San Carlos P, 2011. (USC Translation Projects)

- 13. Alunan, Merlie, translator, and Hope S. Yu, editor. Kay Dili Buta ang Gugma: Because Love is not Blind. NCCA, 2012. (NCCA Translation Projects)

- 14. Yu, Hope S, translator. House of Cards. NCCA, 2013. (NCCA Translation Projects)

- 15. Yu, Hope S., and Trizer Dale Mansueto, translators. Hunger in Nayawak and Other Stories. U of San Carlos P, 2013. (USC Translation Projects)

From these lists, it is evident that there are more published translation projects in English than in Filipino. There are only four translation projects in Filipino while there are fifteen translation projects in English. Given these numbers, it can be inferred that the production of translation projects into English is more preferred than Filipino. This means that English dominates Filipino as the dominant poetics in the translation projects of Cebuano literature. The preference for the English language over Filipino in the translation projects of Cebuano literature is elaborated by different scholars. Alburo, as one of the Cebuano translators that opted to use English language, argues that this is a "result of psychological resistance to the hegemony of Manila," as the major publication resources that writers of Cebuano literature need are located in Manila (Alburo, "Ridling-Ridling of the Ghost Crab" 137). This suggests that Manila predominantly controls publication resources in the country. Given this situation, Cebuano scholars consciously and unconsciously develop a biased perception against the region that uses Filipino language. Moreover, Maria Luisa Torres Reyes and Ubaldo Stecconi also observe the resistance of regional writers to the use of Filipino as the target language in the translation. Reyes and Stecconi's study highlights that the regional writers argue that the national language which is largely based on Tagalog and that it is supposed to have an equal footing with other regional languages because Tagalog is just one albeit being spoken in the National Capital Region. Reyes and Stecconi conclude that for regional writers, the choice of using Filipino reflects a tendency toward domestic hegemony in a multi-cultural setting like the Philippines, which is symptomatic of the country's colonial history (7). Victor Sugbo further explains the dominance of English by stating that the Philippine language policy, since its inception, has favored the English language. By legislating English in the controlling 
domains, policies have marginalized the Philippine languages. Even with the aid of legislation, Filipino/Tagalog, the national language, has assumed secondary status in terms of prestige. Despite its widespread acceptance, Filipino has not succeeded in displacing English in the controlling domains (Sugbo 6). Thus, despite the nationalistic efforts to develop the popularity of Filipino through language planning and policies, the public and private sectors have continued to valorize English, as evinced in the translation projects.

In terms of readership, it can be inferred that in the case of Cebuano translation projects, the use of English language is more preferred than Filipino as a language in translation as it offers readership in the international literary field. Using English instead of Filipino in translating Cebuano literature makes it understandable not only to Filipino readers but to foreign readers as well. This perspective suggests that Cebuano scholars and translators recognize the symbolic, political, and economic power of English language as dominant poetics in the translation projects. It is therefore very ironic that Cebuano scholars resist the use of Filipino for they see it as a domestic hegemony and another form of colonization while almost totally embracing and valorizing the use of English due to its symbolic value even if it is also another form of hegemonic movement. Ultimately, the issue of dominant poetics evident in the language preferences in translation is difficult to resolve especially because it is imposed by patronages. Even though the translators involved in the translation projects are Cebuano, they too have no power in terms of choosing the target language as they only follow the condition imposed by the patronages.

\section{Professionals within the Literary System: Cebuano Scholars and Translators}

The professionals within the system are the Cebuano scholars and translators involved in the translation projects. Since there are two languages to which the projects are translated, there are also two separate groups of Cebuano scholars and translators involved in the process. The Cebuano translators who translated Cebuano literature into Filipino are Nazarion Bas, Don Pagusara, Remedios B. Ramos, Lededica Leyson, Flora G. Empuerto, Romeo S. Macan, Avita A. Perez, Godfrey G. Montera, Geraldine C. Rebamonte, and Rowena C. Largo. On the other hand, the translation projects of Cebuano literature into English are initiated by Resil B. Mojares, Erlinda K. Alburo, Simeon Dumdum Jr., Vicente Bandillo, Merlie Alunan, Hope S. Yu, Haidee Emmie K. Palapar, and Trizer Dale Mansueto.

These Cebuano scholars and translators are those responsible for the creation of the criteria of selection and for the actual selection of Cebuano literature to be translated. The authoritative power that these scholars and translators manifest 
in the selection has greatly influenced the formation of an alternative canon of Cebuano literature, that is, the translated canon of Cebuano literature.

\section{Selection Process: Criteria Imposed by Professionals within the System}

The selection process inescapably involves the concepts of inclusion and exclusion. The concepts of inclusion and exclusion consequently suggest an assignment of value to a literary work. In the discourse of value, Smith defines value as a relative status of a thing, or the estimate in which it is held, according to its supposed worth, usefulness or importance (Smith 178). Smith's definition of value which involves the words "relative," "estimate," and "supposed worth" suggests that value is tentative and can be changed. Thus, Smith states that the value of literary works may be "intrinsic" or "extrinsic" which means that literary judgments can be claimed by "objective validity" (intrinsic) and can also be obtained through "expressions of personal preference" (extrinsic) (177). Due to this, she argues that since the value of literary works is affected by intrinsic and extrinsic judgments, a certain process of evaluation of the value of literary works must be instigated (177). The process of evaluation relies on the criteria used as basis of judgment. Moreover, Smith also says that the evaluation of literary work is seen as a continuous process operated by a wide variety of individuals involved as well as social and institutional activities and practices (181). In short, the evaluation of literary value relies on the criteria imposed as basis of judgment and that the criteria in the evaluation process are made by individuals involved in the institutional practices. Thus, in the making of Cebuano literature translation projects, the responsibility of creating a criteria and selecting canonical Cebuano literature resides exclusively in the professionals within the system. The criteria are held valuable by the professionals within the system which validates their scholarly judgment.

In the case of Cebuano literature translation projects, the discussion of the criteria and the actual selection process are based on the translation programs to which the translation projects belong, namely, the Panitikan Series, Aklat Bahandi Series, KWF-PSWF Translation Project, Solidarity Translation Series, and NCCA Translation projects.

The production of the translation projects under the Panitikan Series does not follow any particular criteria in the selection process as the list of canonical Cebuano writers is initially created by three literary experts from the three prestigious national universities. The created list is then given to the Cebuano scholars for additions and completion of entries in the list. Given this, it can be inferred that only the three literary experts from the national level (Soledad Reyes, Isagani Cruz, 
and Nicanor Tiongson) and the Cebuano scholars (Don Pagusara, Erlinda Alburo, and Resil Mojares) have controlled the selection of canonical Cebuano writers included in the translation projects under the Panitikan Series.

Moreover, the Aklat Bahandi Series published Labindalawang Kuwento ni Vicente Sotto. However, the reason for the selection of Sotto's texts is not clearly stated in the anthology. In order to justify the selection of Sotto's canonical texts, Alburo explains in the introduction:

$[\mathrm{N}]$ ang ilunsad ng National Commission for Culture and the Arts (NCCA), sa pamamagitan ng Literary Arts Committee nito, ang paghahanap ng anim na manunulat mula sa rehiyon upang parangalan ng Gawad Bonifacio, walang pagdadalawang-isip ang pagno-nominate sa nasirang Vicente Y. Sotto (1878-1950) na siyang tinaguriang 'Ama ng Panitikang Sebuano,' para sa panitikang Sebuano. Layunin ng koleksyong ito na maipabasa sa mga Filipino ang orihinal na tekstong Sebuano at ang salin nito sa Filipino ng labindalawang kuwento ni Sotto. (Alburo in Remedios, Labindalawang Kwento ii)

When the National Commission for Culture and the Arts (through its Literary Arts Committee) launched the Gawad Bonifacio Award for six regional writers, the late Vicente Y. Sotto (1878-1950) was without a doubt, nominated to represent Cebuano literature for he was known as the "Father of Cebuano Literature". This collection aims to promote the nationwide readership of the original and Filipino translation of the twelve Cebuano stories written by Sotto. (Alburo in Remedios, Labindalawang Kwento ii)

As can be inferred here, the decision to nominate and select the canonical texts of Sotto for the Gawad Bonifacio is a consensus determined by scholars involved in the project. But the questions of who makes this decision and on what bases are not clearly defined. However, since the editor (Alburo) and the translator (Ramos) of this translation projects are the main persons involved in the creation of the project, it can be inferred that they are the persons mostly responsible in selecting the literary works of Sotto as the "Father of Cebuano Literature."

Meanwhile, the translation project under the Panrehiyong Sentro sa Wikang Filipino (PSWF R-VII) of Cebu Normal University is titled Mga Piling Literaturang Sugbuanon. In this translation project, there is also no clear criteria in the selection of the literary works. In the introduction to this translation project, Leyson, the head of PSWF R-VII, states that the literary texts especially the bugtong (riddle), idyoma (idioms), salawikain (proverbs), and anekdota (anecdotes) included in the project are based on interviews (Mga Piling Literaturang Sugbuanon ii). However, Leyson does not state who the respondents are and how the procedure of the interview was done. Leyson also states that other literary texts such as poems, short stories, and radio-plays included in the translation project were given by the 
authors, and yet, there is no specification on how the selection was done (Mga Piling Literaturang Sugbuanon ii). There is also no mention of a call for submission that might justify the selection of literary texts. Furthermore, an interview with Romeo Macan, one of the researchers/translators of the translation project and the current head of PSWF R-VII, sheds light on the issue. Answering the question on how the selection of the literary works was done, Macan says that "there was no proper criteria in the selection. In fact, the selected literary works were only given to us by Leyson and tasked us to translate the selected works. There was even no call for submissions ... of literary works to be included in the anthology ... it was only Leyson who had the list of Cebuano literary texts to be included in the anthology" Macan ends his statement by stating that "they (translators) were not even consulted on the completion of the project after they had submitted their translations" (Personal Interview). Thus, based on the material analysis of the translation project and the interview with Macan, it appears that Leyson, as the head of PSWF R-VII, controlled the selection of Cebuano literary texts. Moreover, even though the actual translation of the literary works had been done by various translators, Leyson had not properly oriented the committee about the completion of the translation project.

However, the Solidarity Translation Series offers a different scenario in the selection process. There are five translation projects published under this program which cover Cebuano poetry, short story, and drama from the precolonial period to the 21st century. Due to the wide scope of these translation projects, a consistent criteria, created by a committee, were used in the selection process. This committee included Alburo (as the editor), Mojares (as the writer of the critical introductions the series and a translator), Vicente Bandillo, and Simeon Dumdum, Jr. In the selection process, the committee clarified in the preface of each of the translation projects that in selecting texts, the following criteria guided the committee: First is the distribution of texts in time, which means that the included literary works are written during the specific period. Second is the representativeness in themes and styles, which means that the theme and style should reflect the reality and status of Cebuano society during a particular period. Third, and the most important, is that it should have literary merit, which means that the included literary works have gained recognition within the Cebuano community (Alburo et al., Cebuano Poetry 8). These criteria are suitably intended for the translation projects under the Solidarity Translation Series that try to broadly cover Cebuano literature (poetry, short stories, and drama from the precolonial period to the 21st century). Through these criteria, the committee is guided properly in choosing various Cebuano literary works.

Finally, the NCCA and USC Press also published translation projects of Cebuano literature. The translation projects under the NCCA and USC focus more on 
selecting literary texts written by certain selected canonical Cebuano writers such as Austregelina Espina-Moore, Ernesto D. Lariosa, Gardeopatra Quijano, Lamberto G. Ceballos, Gremer Chan Reyes, and Tem Adlawan. These translation projects are mainly collected and edited by Hope S. Yu, the current director of CSC. In an interview, Yu identified the reasons behind her selection of few canonical Cebuano writers in the translation projects. She narrates how her interest in translating literary works of selected canonical writers started:

My translation started as a requirement for my Ph.D. class under Dr. Corazon Villareal. After my class with Dr. Villareal, I had translated three novels of Austregelina Espina-Moore (Inahan ni Mila, Diin may Punuan sa Arbol, and House of Cards). After I was done with my degree, I submitted to the NCCA my translation of Ang Inahan ni Mila and it was published. But there were two more translations that I did which I was planning to submit to NCCA for publication. However, Gremer Chan Reyes, who is also one of the Cebuano canonical writers, asked me to translate his stories and there are also other Cebuano canonical writers such as Ernesto Lariosa, Lamberto G. Ceballos, and Tem Adlawan whose works are worthy to be translated and published. Then I realized that there are so many classical writers out there whose works need to be translated. That realization has corrected the direction of my translation which is to focus on classical writers. (Personal Interview)

Also, in an email exchange with $\mathrm{Yu}$, she further clarifies that "as a scholar in Cebuano literature, I know what works have been published out there. As director of the Cebuano Studies Center, I have decided that since the Cebuano classics have yet to come out in book form, they be given priority not only in publication but translation as well" ("Inquiry on Cebuano Literature" email, February 21, 2016). A material analysis of Yu's translation projects was also done to further show the reasons behind the selection of each of the canonical Cebuano writers. In the case of Austregelina Espina-Moore, Yu states that her selection is based on the literary qualities and intellectual depth of her literary works which fit into the broader category of Cebuano feminist literature (Yu, Mila's Mother i). Moreover, in the case of Gremer Chan Reyes, Yu narrates that her selection of Reyes's short stories started when she spoke and met with Reyes after the Kapulongan: Conversations with Cebuano Writers Class Project in 2008 (Yu, Men at Sea and Other Stories v). Meanwhile, in the selection of the short stories of Gardeopatra Quijano, Yu acknowledges the guidance of Alburo, the director of the USC Cebuano Studies Center in 2010, for suggesting Gardeopatra Quijano as one Cebuano canonical writer worthy of critical study (Yu and Palapar, Himaya nga Nabanhaw vi). Finally, Merlie Alunan explains the selection of Temistokles M. Adlawan and his short stories by stating that "it is Tem Adlawan and our experiences with him that have been directly instrumental in encouraging the translation and publication of this collection (Alunan and Yu, Because Love Is Not Blind iii). 
From the description above, it is clear that $\mathrm{Yu}$ initiated the translation projects under the NCCA and USC. However, it is also observable that there are no consistent criteria in the selection process. The reasons for selecting the identified canonical Cebuano writers as indicated in the interview, email exchange, and in the introductions to the translation projects imply that the selection process was influenced by her personal choices.

The discussion of the criteria of each translation series/program shows that the translation projects under Panitikan Series do not have a specified selection process criteria. This is also the case in the Bahandi Series, KWF-PSWF, and NCCA translation projects. Only the translation projects under the Solidarity Translation Series have imposed a specific criteria in the selection process. Moreover, the selection process of the Panitikan Series, Bahandi Series, KWF-PSWF, and NCCA is guided by the same pattern, which is mainly influenced by the personal choices of the translators and editors involved. For instance, the selection of Cebuano literary works included in the Panitikan Series was done by national literary experts such as Reyes, Cruz, Tiongson and Cebuano scholars such as Alburo, Morajes, and Pagusara. The same scenario of selection happened in the Bahandi Series where Alburo and Ramos controlled the selection. In the case of KWF-PSWF, Leyson, the director of PSWF, manipulated the selection process. Lastly, the translation projects under the NCCA were created and edited by Yu, the current director of CSC. These facts imply that the selection of Cebuano literary works included in the Panitikan, Bahandi, KWF-PSWF, and NCCA translation projects has been arbitrarily made and based on personal choices of the translators and editors. In other words, the selection process was on subjective reasons or expressions of personal preferences. Therefore, the inconsistency in the criteria and the personal choices of the professionals within the system imply that there is politics in the process of selecting what and whose works are to be included in the translation projects. The chances of getting a writer's works translated and published are greater if any or all of these three conditions are met--if the author has literary merit, if the author made a personal request, or if the author was recommended by a Cebuano scholar. This implication appears suspicious and may have a negative impact on the good intentions of Cebuano scholars and translators involved in the translation projects. Furthermore, the effect of this implication appears that there is an uneven and unequal process in the selection of translated literary works. To a large extent, the inconsistency in the criteria and the personal choices of the different translators and editors in the selection process have arbitrarily valorized the selected canonical Cebuano writers and marginalized the unselected ones. Due to this, the power relations employed by the translators and editors suggest that the selection process is unsystematic and seemingly random. This further suggests that 
the published translation projects of Cebuano literature are decidedly preliminary in nature and that a critical criteria in the selection process remain to be developed and established.

All in all, the authoritative power of the professionals within the system which is unsystematic and arbitrary has dictated, reshaped, and misrepresented the traditional canon of Cebuano literature. More than that, the unsystematic nature of the authoritative power of the professionals within the system has created translation projects that are preliminary and arbitrary in nature. Most importantly, the unsystematic authoritative power of the professionals within the system has formed an alternative list of canonical Cebuano literature based on the literary works included in the Cebuano literature translations projects. This alternative list caters to non-Cebuano readers as it is further canonized by the process of translation.

\section{THE FORMATION OF AN “ALTERNATIVE” CANON OF CEBUANO LITERATURE THROUGH TRANSLATION}

From the discussion of the selection process, it appears that canon formation is to a great extent the product of an invocation of power in the criteria of the selection process by the professionals within the system. This means that these professionals which represent certain hegemonic and authoritative power manifested by subjective or personal preferences have dictated and controlled the shaping and reshaping of the canon. In the case of Cebuano literature translation projects, the hegemonic and authoritative power manifested by subjective preferences of the different professionals has created an inconsistent and unsystematic selection criteria. In effect, the criteria have also created an alternative list of canonical Cebuano literature that is preliminary and provisional in nature.

In the discourse of canonicity, Guillory underscored that canon formation is related to power as canonicity "implies, reflects, and builds on authority and that canons are instruments of power" (110). Hence, the alternative list of canonical Cebuano literature, despite its tentativeness, is an instrument of cultural power and literary richness of Cebuano community and that the formation of Cebuano literary canon throughout history implies, reflects, and builds on prestige and authority. This suggests that the alternative list of canonical Cebuano literature evident in the translation projects has gained prestige and recognition not only through the cultural power and literary richness thought to be evident in their literary works, but also because they are considered canonical by the Cebuano scholars and readers themselves. What is more, their being part of the canon is 
reinforced by the power of being translated into other languages. It is therefore clear that the alternative list of canonical Cebuano literature included in the translation projects has undergone the process of translation as imposed by the patronages. In this way, the preliminary and provisional alternative list of canonical Cebuano literature is further canonized by the translation process. This goes to show that translation as one cultural practice consequently promotes the formation of an alternative canon of Cebuano literature-an alternative canon that is translated and therefore understandable to non-Cebuano readers. This canon is parallel to and autonomous from the traditional canon of Cebuano literature.

The role of translation in the canon formation is explained by Lawrence Venuti in his argument that "the cultural power of translation is uniquely revealed when we consider its role in the canonization of a literary text" as "translation functions as one cultural practice through which a text attains the status of a classic by the very fact... that the text has been judged valuable enough to bring into another culture which occupies a higher status (48). Indeed, the selected canonical Cebuano literature included in the translation projects has been judged valuable enough to be included in the alternative list of canonical Cebuano literature. Then, the process of translation has introduced the selected canonical Cebuano literature into other cultures which have higher readership, the cultures of the target languages of Filipino and English. Venuti also argues that the translation of a canonical texts can be considered successful, if it meets at least two conditions. First is application of dominant formal and thematic interpretation and conventions of the dominant target culture. Second, literary value must be supported and increased by cultural and social factors such as editors, publishers, reviewers, and readers (51). Thus the idea of introducing an alternative list of canonical Cebuano literature through translation which is imposed by patronages and supported by the professionals within the system (translators and editors) is an indication that the canonization process is considered successful. The success of the formation of an alternative canon of Cebuano literature through translation has introduced Cebuano literature to the culture of national readers who understand Filipino and English.

In this way, the process of translation has not only canonized and valorized Cebuano literature by making it understandable to non-Cebuano readers in the national arena; rather, it has also valorized the value that circulates in the academe and institutions. Translating Cebuano literature to Filipino and English integrates it to the formation of a national literature. Therefore, the process of translation does not only aid in the formation of an alternative canon of translated Cebuano literature, but it has also contributed to the formation of a national literary canon. This goes to show that the dominant force that has influenced the production and canon formation of Cebuano literature through translation is the formation of a national literary canon. 


\section{CONCLUSION}

The production and canon formation of translated Cebuano literature are indeed driven by the politics of translation. This politics is initially shown in the literary history of Cebuano literature as the reason behind the publication of Cebuano literature which responds to the campaign for the formation of a national literature that includes regional literatures of the Philippines. In the production process, the politics of translation is manifested by the political agenda of the factors that control the production of Cebuano literature translation projects. This political agenda refers to the imposition of translation using Filipino and English in the publication of Cebuano literature. Lastly, in the canon formation, the politics of translation is manifested in the selection process where the criteria are largely based on the personal choices of the involved Cebuano translators and editors. Moreover, the politics of translation is also shown in the canonization of the alternative canon of translated Cebuano literature where translation has introduced the alternative canon of translated Cebuano literature to the higher culture of the national arena, a culture that uses Filipino and English languages.

Furthermore, this study establishes that the role of translation in the production and canon formation processes changes accordingly. It is shown in the production process that the role of translation reveals the collaboration among the constituencies involved. However, the collaboration among the constituencies is unequal as the sponsoring institutions (patronages) can impose conditions in the publication process, whether to use Filipino or English translation. Moreover, in the politics of canon formation, the role of translation has not only formed an alternative canon of translated Cebuano literature but has also valorized the culture of the national arena by translating the selected alternative canon of Cebuano literature into Filipino and English. These changing roles of translation have clarified and established the fact that the analysis of the production and canon formation processes always loops back to the notion of using Filipino and English translation for the formation of a national literature.

Therefore, the overall politics that dictates the production and canon formation of Cebuano literature through translation is the valorization of the dominant value that circulates in the academe and institutions which support the production of Cebuano literature translation projects, that is, the rise of vernacular literature in order to form regional canons that are needed in the formation of a national literary canon. 


\section{Works Cited}

Abad, Gemino. Our Scene so Fair: An Overview of Filipino English Poetry, 1905 to 1995. U of the Philippines P, 2008.

Abueg, Efren R. editor. Manunulat: Mga Piling Akdang Pilipino. Pioneer Printing, 1970.

Alburo, Erlinda K. Cebuano Folksongs 1. University of San Carlos Publications, 1978.

-.. Cebuano Folktales 1 and 2. University of San Carlos Publications, 1977.

--. "Notes on the Language Issue, Cebuano Literature, and National Identity." Philippine Quarterly of Culture and Society, vol. 18, 1990, pp. 312-322.

--. "Ridling-Ridling of the Ghost Crab: Translating Literature in Cebuano." Translation in Asia: Theories, Practices, and Histories, edited by Ronit Ricci and Jan van der Putten, St. Jerome Publishing, 2011, pp. 136-140.

-.. Tigmo ug Sanglitanan: Cebuano Riddles and Proverbs. Cebuano Studies Center, University of San Carlos, 2002.

Alburo, Erlinda, Resil Mojares, and Don Pagusara. Dulaang Cebuano. Ateneo de Manila UP, 1997.

Alburo, Erlinda, Vicente Bandillo, Resil Mojares, and Simeon Dumdum, Jr, editors. Cebuano Poetry: Sugboanong Balak 1940-1988. Cebu Studies Center, University of San Carlos, 1988.

-.. Cebuano Poetry: Sugboanong Balak until 194o. Cebu Studies Center, University of San Carlos, 1988.

-.-Panulaang Cebuano. Ateneo de Manila UP, 1993.

--. Sugilanong Sugbuanon: Cebuano Fiction 1941-2005. Ateneo de Manila UP, 2009.

-.. Sugilanong Sugbuanon: Cebuano Fiction until 194o. Ateneo de Manila UP, 2009.

Alunan, Merlie, editor. Because Love Is Not Blind: Short Stories of Temosticles Adlawan, translated by Hope Yu, National Commission for Culture and the Arts, 2012.

Bresnahan, Roger. Angles of Vision. New Day, 1992.

Cebuano Studies Center. http://www.cebuanostudiescenter.com (accessed February 5, 2016)

Guillory, John. Cultural Capital: The Problem of Literary Canon Formation. U of Chicago P, 1993.

History of Cebuano Studies Center. http://www.cebuanostudiescenter.com. Accessed 5 Feb. 2016.

History of the KWF. http://kwf.gov.ph/. Accessed 5 Feb. 2016.

History of the NCCA. http://ncca.gov.ph/. Accessed 5 Feb. 2016.

Jose, Francisco Sionil. “The Story of Solidarity." Solidarity, no. 135-136, 1992, pp. 8-17

Lado, Beatrice. "Linguistic Landscape as a Reflection of the Linguistic and Ideological Conflict in the Valencian Community." International Journal of Multilingualism, vol. 8, no. 2, 2011, pp. 135-150

Lefevere, André. Translation, Rewriting and the Manipulation of the Literary Fame. Routledge, 1992. 
Leyson, Lededica, Flora Empuerto, Romeo Macan, Avita A. Perez, Godfrey Montera, Geraldine Rebamonte, Rowena C. Largo, editors. Mga Piling Literaturang Sugbuanon. PSWF R-VII, 2008.

Lorente, Beatriz. "Mapping English Linguistic Capital: The Case of Filipino Domestic Workers in Singapore." PhD diss., National University of Singapore, 2007.

Lumbera, Bienvenido, editor. Filipinos Writing: Literature from the Regions. Anvil, 2001.

--. "The Literary Relations of Tagalog Literature." Brown Heritage, edited by Antonio G. Manuud. Ateneo de Manila UP, 1967, pp. 308-330.

--. "Versus Exclusion: The Political Dynamics between the "National" and the "International" in Contemporary Philippine Literary History (1946-2006)." Likhaan 3, 2010, pp. 179-187.

Lumbera, Bienvenido, and Cynthia Lumbera. Philippine Literature: A History and Anthology. Anvil, 1997.

Macan, Romeo. Personal Interview, March 13, 2017.

Maceda, Teresita. "Central Visayas Literature." Filipinos Writing: Literature from the Regions, Anvil, 2001, pp. 381-385.

Mojares, Resil. “Do Regional Literatures Exist Today?” Solidarity, no. 108-109, 1986, pp. 128-130.

--. "On Native Grounds: The Significance of Regional Literature." Literature and Society Cross Cultural Perspectives: The Proceedings of the Eleventh American Studies Seminar. Los Baňos, Philippines. October 1976.

Ordonez, Elmer. Emergent Literature: Essays on Philippine Writing. U of the Philippines P, 2001.

Puente, Lorenzo Alexander L. "Translation in a Postcolonial Context: Translating N.V.M. Gonzalez's A Season of Grace." Master's Thesis, Ateneo de Manila University, 1997.

Ramas, Wilhelmina Q. "Sugbuanon Literature." Literature and Society Cross-Cultural Perspectives: The Proceedings of the Eleventh American Studies Seminar. Los Baňos, Philippines, October 1976.

Ramos, Remedios B. Labindalawang Kuwento ni Vicente Sotto. UP Sentro ng Wikang Filipino, 1998.

Reyes, Maria Luisa, and Ubaldo Stecconi. "Transgression and Circumvention through Translation in the Philippines." Translation as Intercultural Communication: Selected Papers from the EST Congress in Prague, edited by Mary Snell-Hornby, Zuzana Jettmarova, and Klaus Kaindl, John Benjamins Publishing Company, 1995, pp.167-17o.

Smith, Barbara Herrnstein. "Value/Evaluation." Critical Terms of Literary Study, edited by Frank Lentricchia and Thomas McLaughlin, U of Chicago P, 1995, pp.179-182.

Sugbo, Victor, "Language Policy and Local Literature in the Philippines." Paper at the International Conference on Language Development and Revitalization of Languages, Bangkok (Nov. 2002)

Toyota Foundation Occasional Report no. 35. International Institute for Asian Studies, June 2005, http://iias.asia/iiasn/iiasn5/toyota.html. Accessed 29 Aug. 2017.

Kritika Kultura 33/34 (2019/2020): 272-274 
Venuti, Lawrence. "Translation, Interpretation, and Canon Formation." Translation and the Classic: Identity as Change in the History of Culture, edited by Alexandra Lianeri and Vanda Zajko, Oxford UP, 2008, pp.27-49.

Yu, Hope S. Ang Inahan Ni Mila/Mila's Mother: A Novel by Austregelina Espina-Moore. National Commission for Culture and the Arts, 2008.

--. Crack Shot and Other Short Stories. U of San Carlos P, 2010.

-.- "Culture on Trial: Gremer Chan Reyes' Men at Sea." Kritika Kultura, no. 21/22, 2013/2014, pp. 210-220.

--. Diin May Punoan sa Arbol/ Where a Fire Tree Grows. U of San Carlos P, 2010.

-.. House of Cards. National Commission for Culture and the Arts, 2013.

--, translator. Men at Sea and Other Stories: Short Stories of Gremer Chan Reyes. National Commission for Culture and the Arts, 2009.

--. "Inquiry on Cebuano Literature" email, February 21, 2016.

--. Personal Interview, March 12, 2017.

Yu, Hope S., and Haidee Emmie K. Palapar, translators. Himaya nga Nabanhaw ug Uban pang mga Sugilanon/Reawakened Bliss. U of San Carlos P, 2011.

Yu, Hope S., and Trizer Dale Mansueto, translators. Hunger in Nayawak and Other Stories. U of San Carlos P, 2013.

Zafra, Galileo. "In Focus: Pushing the National Language Development through

Translation." NCCA articles, 2004, p. 6. 